\title{
Nutritional and Microbiological Quality of Tiger Nut Tubers (Cyperus esculentus), Derived Plant-Based and Lactic Fermented Beverages
}

\author{
Elena Roselló-Soto ${ }^{1}$, Cyrielle Garcia ${ }^{2}$, Amandine Fessard ${ }^{2}$, Francisco J. Barba ${ }^{1}$ (D), \\ Paulo E. S. Munekata ${ }^{3}$, Jose M. Lorenzo ${ }^{3}$ (D) and Fabienne Remize ${ }^{2, *(D)}$ \\ 1 Nutrition and Food Science Area, Preventive Medicine and Public Health, Food Science, \\ Toxicology and Forensic Medicine Department, Universitat de València, Avda. Vicent Andrés Estellés, \\ s/n 46100 Burjassot, València, Spain; eroso2@alumni.uv.es (E.R.-S); francisco.barba@uv.es (F.J.B.) \\ 2 QualiSud, Université de La Réunion, CIRAD, Université Montpellier, Montpellier SupAgro, \\ Université d'Avignon, 2 rue J. Wetzell, F-97490 Sainte Clotilde, France; \\ cyrielle.garcia@univ-reunion.fr (C.G.); amandine.fessard@hotmail.fr (A.F.) \\ 3 Centro Tecnológico de la Carne de Galicia, rúa Galicia n 4, Parque Tecnológico de Galicia, \\ 32900 San Cibrao das Viñas, Ourense, Spain; pmunekata@gmail.com (P.E.S.M.); \\ jmlorenzo@ceteca.net (J.M.L.) \\ * Correspondence: fabienne.remize@univ-reunion.fr; Tel.: +262-692-200-785
}

Received: 12 November 2018; Accepted: 19 December 2018; Published: 20 December 2018

check for updates

\begin{abstract}
Tiger nut (Cyperus esculentus) is a tuber that can be consumed raw or processed into beverages. Its nutritional composition shows a high content of lipid and dietary fiber, close to those of nuts, and a high content of starch, like in other tubers. Tiger nuts also contain high levels of phosphorus, calcium, and phenolic compounds, which contribute to their antioxidant activity. From those characteristics, tiger nuts and derived beverages are particularly relevant to limit food insecurity in regions where the plant can grow. In Europe and United States, the tiger nut derived beverages are of high interest as alternatives to milk and for gluten-free diets. Fermentation or addition of probiotic cultures to tiger nut beverages has proven the ability of lactic acid bacteria to acidify the beverages. Preliminary sensory assays concluded that acceptable products are obtained. In the absence of pasteurization, the safety of tiger nut-based beverages is not warranted. In spite of fermentation, some foodborne pathogens or mycotoxigenic fungi have been observed in fermented beverages. Further studies are required to select a tailored bacterial cocktail which would effectively dominate endogenous flora, preserve bioactive compounds and result in a well-accepted beverage.
\end{abstract}

Keywords: tiger nuts; horchata; lactic fermentation; beverage; quality; product development

\section{Introduction}

Increased consumption of fruits and vegetables is recognized to protect against non-communicable diseases [1,2]. Health benefits of fruit and vegetable intake have been historically related to their high content in vitamins, minerals, and phytochemicals. They are also recommended as a source of dietary fibers. For this purpose, starchy roots and tubers have a considerable role for carbohydrate and dietary fiber intake [3]. This role is of great importance for gluten-free diets, which are characterized by insufficient dietary fiber uptake [4-6]. In addition, comparatively to dairy products, plant-based materials do not contain lactose or dairy allergens and exhibit low cholesterol content. Moreover, they benefit from a vegan-friendly status. Among plant-based alternatives to milk, the most popular are soya, almond- and rice-based beverages, but other substitutes, either directly obtained from traditional edible plant extraction, either fermented, are gaining interest as the market is rapidly expanding [6-8]. 
Lactic fermentation is a traditional and sustainable way to increase the shelf-life of food products as well as to change texture, flavor, and taste $[9,10]$. In addition, depending on the bacterial strains, a probiotic effect, defined as a health benefit on the host, conferred by living microorganisms administered in adequate amounts, can be expected [11].

Historically, lactic fermentation has been applied to a variety of raw materials, including milk, meat, fish, cereals, vegetables, and fruits [9,12-14]. Lactic fermentation of cereals, including maize, millet, barley, oats, rye, wheat, rice or sorghum, into beverages is ancestral and commonly used in Africa $[7,15]$. Lactic fermented beverages obtained from teas or vegetables or fruits, with high functional value, were also described $[16,17]$. The development of new lactic-fermented products is explored worldwide and is recognized as the most suitable way for increasing the daily consumption of fresh-like vegetables and fruits $[7,10,16]$.

Tiger nut (Cyperus esculentus) is a tuber, mainly harvested in Spain, West Africa countries like Nigeria, Senegal, or Ghana, and also in South America, as in Chile [18,19]. From an economic point of view, tiger nut is described as an underutilized African crop with high potential for development [20]. Because of its ecological plasticity and its invasive capacity, this plant is considered as a weed or a crop depending on the context [18]. In West Africa, the tubers are often part of the diet as they are cheap, available all the year around, and with nutritional benefits [20]. Recent market changes show how innovative tiger nut based beverages are arising around Europe and this tuber is becoming popular in the US [21].

Nutritional composition of tiger nut tubers shows some unique features, between other tubers and nuts [19]. Starch content of tiger nut is closely related to that of cassava, whereas lipid and even more fiber contents resemble those found for almonds or pistachios. Its composition and associated health benefits offer to this tuber a huge potential for product development. Nowadays, tubers are consumed raw, roasted or after transformation into beverage or flour. The beverage is obtained after several washing steps to eliminate dusts and poor-quality tubers, soaking overnight the dry tubers in water, disinfection with chlorinated water, blending with water, pressing, and filtering (Figure 1).

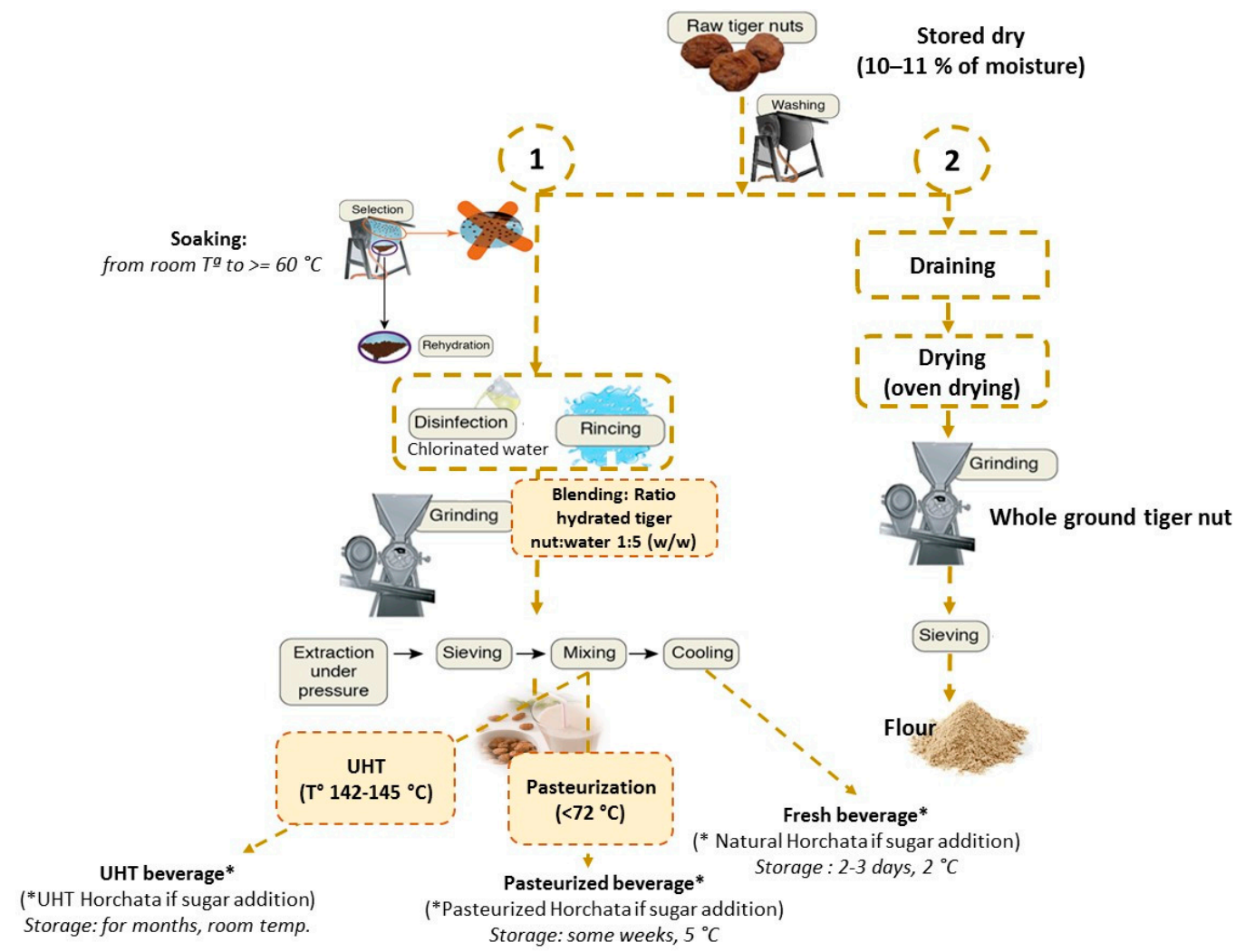

Figure 1. Flowchart showing industrial processing of tiger nuts (1) beverages and (2) flours. 
The beverages obtained from this process are called improperly tiger nut milk [22,23] or juice [24]. In Spain, added with a minimum of $10 \%$ sugar, this is the very popular drink called "Horchata". Processing this product is regulated: a minimum of $12 \mathrm{Brix}, 1.9 \%$ of starch, $2 \%$ of fats, total sugars expressed as sucrose of $10 \%$, and a $\mathrm{pH}$ above 6.3 [25]. Horchata can be produced fresh, pasteurized, sterilized, concentrated or even in powder. When heat treatments are applied, an amylolytic step is required before applying a temperature above $75^{\circ} \mathrm{C}$ to avoid starch gelatinization. Whole ground tiger nut and flour are also commercialized. Both the fermentation of tiger nut derived beverage or the addition of probiotic cultures have been evaluated in several studies, resulting in tiger nut yogurts [23,26-31]. Moreover, the "Horchata" production process results in several by-products, such as the drained-water, which is suitable for other applications [32].

This review examines the latest description of nutritional composition, together with microbiological quality, of tiger nuts and derived beverages. We provide a review of the impact of lactic fermentation on the quality of tiger nut beverages. From those data, we focus on the relevance of the consumption of fermented beverages and their potential for new product development.

\section{Nutritional Characteristics and Bioactive Compounds of Tiger Nut}

The energy value of tiger nut tuber ranges within 400-413.8 kcal/100 g [19,33]. The main components of tiger nut are carbohydrates, which represent $43.3 \mathrm{~g} / 100 \mathrm{~g}$. Starch content, $29.9 \%$ in wet matter, is similar to that of cassava and about twice that of potato [19]. Dietary fiber content, of $8.81 \mathrm{~g} / 100 \mathrm{~g}$, is much higher than in other tubers, which contain $0.66-2.55 \mathrm{~g} / 100 \mathrm{~g}$, and in similar ranges than nuts. It is constituted of insoluble dietary fiber at $99.8 \%$. Sucrose content, $13.03 \mathrm{~g} / 100 \mathrm{~g}$, is also much higher than in other tubers, ranging from 0.31 to $4.77 \mathrm{~g} / 100 \mathrm{~g}$.

Tiger nut contains $22 \%$ to $45 \%$ of fat in dry matter, depending on the origin of the tubers [34]. In wet matter, due to a higher moisture content of ca. $26 \%$, lipid content is lower than in tree nuts.

The examination of the fat structure in seed oils obtained from tiger nut showed that neutral lipids, dominated by triacylglycerols constitute the bulk of lipids and represent $65.9 \%$ of total lipids, while glycolipids and phospholipids represent $5.6-6.9 \%$ and $1.4-3.1 \%$, respectively. The structural feature is consistent with most vegetable oils, with monounsaturated acids predominantly found in greater amounts at the sn-2 position, and a lower prevalence of saturated fatty acids, located in the sn- 1 and sn-3 positions [35,36]. The main fatty acids are oleic $56 \%$ to $85 \%$, palmitic $10 \%$ to $20 \%$, linoleic $8 \%$ to $12 \%$ and stearic $0.3 \%$ to $5.3 \%$ acids $[19,34,37,38]$, while the minor acids were linolenic and palmitoleic [35]. Tiger nuts composition in monounsaturated fatty acids is in agreement to that found for olive oil, being the fatty acid profile used as a possible geographical authenticity marker. Tiger nut naturally contains a number of sterol components that are of a different composition than the components found in olive oil. $\beta$-sitosterol was found as the main compound ( $\approx 49-60 \mathrm{mg} / 100 \mathrm{~g}$ ), followed by stigmasterol, campesterol, $\alpha$ and $\beta$-tocopherols [39].

Protein content in tiger nut (5.04-6.67\% wet matter) is higher than that found in other tubers, but lower than in nuts. For instance, the protein content of tubers ranges from $0.66 \%$ in sweet potato to $2.55 \%$ in yam, whereas pine nuts and peanuts contain $13.7 \%$ and $25.8 \%$ of proteins, respectively [19]. The predominant protein fraction (82-91\%) corresponds to the water-soluble fraction of albumin and non-protein nitrogen. The analysis of these fractions by electrophoresis presented a high diversity in polypeptide molecular weights, highlighted at 20, 25, 37, 55, 75 and $106 \mathrm{kDa}$. The other solubilized fractions of globulins (1.11-3.96\%), prolamins (0.91-3.45\%) and glutelins $(0.63-1.98 \%)$ presented a pattern with fewer different molecular weight polypeptides [40]. The amino acid profile shows, in decreasing order, aspartic acid, glutamic acid, leucine, alanine and arginine [37]. In addition to protein anabolism, L-Arginine is of particular interest as it is the main precursor of nitric oxide (NO), a non-adrenergic and non-cholinergic neurotransmitter involved in numerous physiological and signaling processes, with a strong vasodilator action. For instance, a dried defatted tiger nut tuber dietary supplementation of rats fed with L-NAME nitric oxide synthase inhibitor (Nw-nitro-L-arginine methyl ester hydrochloride) presented an effect on NO metabolism, preventing the reduction in 
the production of nitric oxide synthesis markers in serum and penile tissue. It also prevented the increased activity of enzymes like acetylcholinesterase, arginase, and adenosine deaminase, leading to the inhibition of NO production whether on serum, on brain or on penile tissue [41].

Tiger nut tubers exhibit high calcium, and phosphorus mineral contents [33,34,37]. On the other hand, magnesium, manganese, iron, zinc and copper are also present, but at lower levels.

Apart from those main characteristics, phenolic and anti-nutrient compounds were analyzed $[38,42,43]$ (Table 1 ). Phytates represented $\approx 21.4 \mathrm{mg} / 100 \mathrm{~g}$ in raw tubers, oxalates $\approx 13.1 \mathrm{mg} / 100 \mathrm{~g}$, alkaloids $\approx 2.6 \mathrm{mg} / 100 \mathrm{~g}$ and tannins $\approx 2.4 \mathrm{mg} / 100 \mathrm{~g}$. The content of all these families of compounds was decreased after soaking, with a more marked effect when soaking was performed at $60^{\circ} \mathrm{C} / 7 \mathrm{~h}$ compared to room temperature $12 \mathrm{~h}$ [42]. The highest decrease was observed for tannins (61\%), followed by oxalates with $(58 \%)$ and polyphenols (48\%). The main discrepancies were observed with the data published by Chukwuma et al. (2010) [43], but for tannins, phytates and polyphenols, the contents were 100-fold below those observed in other tubers or in chickpeas [44-46]. The composition analysis shows that trans-ferulic acid, vanillic acid, vanillin and trans-cinnamic acid are the main phenolic compounds in tiger nut oils [38]. Moreover, the antioxidant activity of tiger nut polyphenols was investigated in comparison with flavonoids from a chemoprotective perspective. A dietary supplementation with $25 \%$ of whole tiger nut showed moderate renal and hepatoprotective properties against acrylamide-induced toxicity in rats [47].

Table 1. Phenolic profile of tiger nut.

\begin{tabular}{|c|c|c|}
\hline Compound & Concentration & Ref. \\
\hline Apigenin & 7.91-50.58 mg GAE/100 g & [48] \\
\hline \multirow[t]{2}{*}{ Caffeic acid } & $1.07-15.25 \mathrm{mg}$ GAE$/ 100 \mathrm{~g}$ & [48] \\
\hline & $3.90-102.19 \mu \mathrm{g} \mathrm{RE} / \mathrm{kg}$ & [49] \\
\hline (Epi)Catechin & $8.83 \times 10^{-4}-6.58 \mathrm{mg} \mathrm{GAE} / 100 \mathrm{~g}$ & [48] \\
\hline Cinnamic acid & $0-40.66 \mu \mathrm{g} \mathrm{RE} / \mathrm{kg}$ & [49] \\
\hline \multirow[t]{3}{*}{ Coumaric acid } & $0-6801.0 \mu \mathrm{g} / \mathrm{g}$ & [50] \\
\hline & $4.20 \times 10^{-4}-17.25 \mathrm{mg}$ GAE $/ 100 \mathrm{~g}$ & [48] \\
\hline & $0-126.76 \mu \mathrm{g} \mathrm{RE} / \mathrm{kg}$ & [49] \\
\hline \multirow[t]{3}{*}{ Ferulic acid } & $3.5-2,284 \mu \mathrm{g} / \mathrm{g}$ & [50] \\
\hline & 33.79-58.38 mg GAE/100 g & [48] \\
\hline & $0-22.33 \mu \mathrm{g} \mathrm{RE} / \mathrm{kg}$ & [49] \\
\hline Diferulic acid & $0.0-829.0 \mu \mathrm{g} / \mathrm{g}$ & [50] \\
\hline Ferulic acid-4-O-glucoside & $0-46.95 \mu \mathrm{g} \mathrm{RE} / \mathrm{kg}$ & [49] \\
\hline Gallic acid & $3.95 \times 10^{-3}-1.74 \mathrm{mg} \mathrm{GAE} / 100 \mathrm{~g}$ & [48] \\
\hline Homovanillyl alcohol & $0-4.54 \mu \mathrm{g} \mathrm{RE} / \mathrm{kg}$ & [49] \\
\hline \multirow[t]{2}{*}{$p$-Hydroxybenzaldehyde } & $0-16.47 \mathrm{mg}$ GAE $/ 100 \mathrm{~g}$ & [48] \\
\hline & $4.0-337.0 \mu \mathrm{g} / \mathrm{g}$ & [50] \\
\hline \multirow[t]{3}{*}{$p$-Hydroxybenzoic acid } & $0-8.3 \mu \mathrm{g} / \mathrm{g}$ & [50] \\
\hline & 2.18-29.12 mg GAE/100 g & [48] \\
\hline & $2.52-67.70 \mu \mathrm{g} \mathrm{RE} / \mathrm{kg}$ & [49] \\
\hline Isohydroxymatairesinol & $0-1331.45$ & [49] \\
\hline Kaempferol & 3.62-24.44 mg GAE/100 g & [48] \\
\hline Luteolin & $7.29-72.17 \mathrm{mg} \mathrm{GAE} / 100 \mathrm{~g}$ & [48] \\
\hline 24-Methylcholestanol ferulate & $0-45.40 \mu \mathrm{g} \mathrm{RE} / \mathrm{kg}$ & [49] \\
\hline Naringenin & $2.38 \times 10^{-3}-16.16 \mathrm{mg} \mathrm{GAE} / 100 \mathrm{~g}$ & [48] \\
\hline Peonidin & $0-7.81 \mu \mathrm{g} \mathrm{RE} / \mathrm{kg}$ & [49] \\
\hline Protocatechuic acid & $0.61-0.79 \mathrm{mg}$ GAE $/ 100 \mathrm{~g}$ & [48] \\
\hline Quercetin & $3.76 \times 10^{-3}-60.63 \mathrm{mg} \mathrm{GAE} / 100 \mathrm{~g}$ & {$[48]$} \\
\hline trans-Resveratrol-3-O-glucoside & $0-25.68 \mu \mathrm{g} \mathrm{RE} / \mathrm{kg}$ & [49] \\
\hline Scopoletin & $0-310.80 \mu \mathrm{g} \mathrm{RE} / \mathrm{kg}$ & [49] \\
\hline Sesamin & $0-28.67 \mu \mathrm{g} \mathrm{RE} / \mathrm{kg}$ & [49] \\
\hline Sinapinic acid & $8.53 \times 10^{-1}-20.97 \mathrm{mg} \mathrm{GAE} / 100 \mathrm{~g}$ & [48] \\
\hline
\end{tabular}


Table 1. Cont

\begin{tabular}{ccc}
\hline Compound & Concentration & Ref. \\
\hline Sinensetin & $0-16.07 \mu \mathrm{g} \mathrm{RE} / \mathrm{kg}$ & {$[49]$} \\
Syringic acid & $4.58 \times 10^{-4}-4.12 \mathrm{mg} \mathrm{GAE} / 100 \mathrm{~g}$ & {$[48]$} \\
Vanillic acid & $3.0-25.3 \mu \mathrm{g} / \mathrm{g}$ & {$[50]$} \\
& $5.88-15.20 \mathrm{mg} \mathrm{GAE} / 100 \mathrm{~g}$ & {$[48]$} \\
& $0-10.84 \mu \mathrm{g} \mathrm{RE} / \mathrm{kg}$ & {$[49]$} \\
Vanillin & $15.5-68.7 \mu \mathrm{g} / \mathrm{g}$ & {$[50]$} \\
ethyl Vanillin & $0-25.38 \mu \mathrm{gE} \mathrm{RE} / \mathrm{kg}$ & {$[49]$} \\
4-Vinylphenol & $0-1084.48 \mu \mathrm{g} \mathrm{RE} / \mathrm{kg}$ & {$[49]$} \\
\hline
\end{tabular}

GAE: Gallic Acid Equivalent; RE: resveratrol Equivalent.

\section{Nutritional Characteristics of Tiger Nut-Based Beverages}

The main composition of tiger nut-based beverages, i.e., Horchata de Chufa and juices, is presented in Table 2.

Table 2. Proximate major nutritional content in tiger nut tubers and beverages.

\begin{tabular}{ccccc}
\hline Nutrient & $\begin{array}{c}\text { Tiger Nut Tuber } \\
(\mathbf{g} / \mathbf{1 0 0 g})^{\mathbf{a}}\end{array}$ & $\begin{array}{c}\text { Horchata De Chufa } \\
(\mathbf{g} / \mathbf{1 0 0 g})^{\mathbf{a}}\end{array}$ & \multicolumn{2}{c}{$\begin{array}{c}\text { Tiger Nut Beverage } \\
(\mathbf{g} / \mathbf{1 0 0 g})\end{array}$} \\
\hline Total fat & 24.49 & 3.09 & $1.26-1.59^{\mathrm{b}}$ & $1.88^{-2.27^{\mathrm{c}}}$ \\
SFA (\% total fatty acid) & 17.5 & & & \\
MUFA (\% total fatty acid) & 72.9 & & & \\
PUFA (\% total fatty acid) & 9.3 & & & \\
Ratio $n-6 / n-3$ & 22 & 0.91 & $2.34-2.51^{\mathrm{b}}$ & $0.47-0.54^{\mathrm{c}}$ \\
Proteins & 5.04 & 0.25 & $0.31-0.39 \mathrm{~b}$ & $0.16-0.18^{\mathrm{c}}$ \\
Ash & 1.7 & $n d$ & $1.93-2.34^{\mathrm{b}}$ & $2.31-2.74^{\mathrm{c}}$ \\
Carbohydrates & 43.3 & 1.03 & $0.23-0.31^{\mathrm{b}}$ & $0.53-0.65^{\mathrm{c}}$ \\
Total dietary fiber & 8.91 & $>10$ & & \\
Sucrose & 13.03 & $>71.45$ & $28.42-33.71^{\mathrm{b}}$ & $28.04-33.55^{\mathrm{c}}$ \\
Total energy (kcal/100g) & 413.8 & & & \\
\hline
\end{tabular}

a data from Sanchez-Zapata 2012 [19], Horchata de Chufa was prepared from tiger nut beverage and additives including more than $10 \%$ of sucrose; ${ }^{\mathrm{b}}$ Tiger nut beverage was obtained by soaking Nigerian tiger nut in water $(1: 3 w / v)$ for $10 \mathrm{~h}$, then by blending drained nuts with water $(1: 5 w / v)$. The resulting homogenous slurry was filtered using a muslin cloth and the resultant filtrate was pasteurized at $67^{\circ} \mathrm{C}$ for $30 \mathrm{~min}$ [24]; ${ }^{\mathrm{C}} \mathrm{To}$ obtain tiger nut beverage, tiger nut from Ghana were first dried for two months at room temperature. The nuts were hydrated by soaking in a water bath for $24 \mathrm{~h}$ at $40{ }^{\circ} \mathrm{C}$ then grinded with water $(1: 4 w / v)$. Finer particles were obtained by dispersing the sample with ultra-turrax mixer at 13,000 rpm for $20 \mathrm{~min}$ and were then transferred into a pneumatic press using one volume of water, to be filtered through a $4 \mu \mathrm{m}$-pore-size filter membrane [51]; SFA: saturated fatty acids; MUFA: monounsaturated fatty acids; PUFA: polyunsaturated fatty acids; nd: not determined value.

As can be seen in the table, tiger nut beverage, which differed from that of "Horchata" in the fact that there is no sucrose addition, exhibits energy values ranging from 28.42 to $33.55 \mathrm{kcal} / 100 \mathrm{~mL}$ [19,42]. These values are close to those of skim cow milk (33 kcal/100 mL), and in the early window by comparison with soy-based "milk" alternatives, which range from 33 to $58 \mathrm{kcal} / 100 \mathrm{~mL}$. The overall plant-based "milk" alternatives present a larger range (12-92 kcal/100 mL).

A protein content between $0.47-2.51 \%$ can be expected in tiger nut beverages according to the process of extraction $[24,51]$. Considering the plant-based "milk" alternatives, the highest overall protein content is found in soy-based beverages, ranging from 2.50 to $3.16 \%$ whether rice and almond-based "milk" alternatives exhibit the lowest protein content with $0.28 \%$ and $0.31-0.59 \%$, respectively [52]. The tiger nut beverage concentration of essential amino acids is $14.27 \mathrm{~g} / 100 \mathrm{~g}$ of proteins, which represents $\approx 28 \%$ of the total amino acid content. It can be observed that leucine is the limiting amino acid [24]. Although the tiger nut beverage amino acid scores are lower than the few existing values, namely for quinoa or soy, which have amino acid scores all above $100 \%$, the essential amino acid composition is of interest and differs from some other plant-based beverage proteins. 
Methionine and cysteine show a relative abundance in tiger nut whereas they are the limiting amino acids in pea, almond and soy proteins [52]. The calculation of tiger nut beverage amino acid score values [53] ranged from $29 \%$ for leucine to $87 \%$ for methionine plus cysteine for infants/pre-school children, and $31 \%$ to $102 \%$ respectively for adults.

The fat content of tiger nut tuber is far above those of beverages, and as expected from tuber composition, the lipid fraction is mainly composed of oleic, palmitic, and linoleic acids. Interestingly, the fractionation of compounds between beverage and residue fraction is dependent on the compound family, being approximately 4:1 for protein, lipid, salts, and soluble fiber, whereas it is 1:6 for insoluble fiber and 1:1 for carbohydrates [51].

Tiger nut beverage is an emulsion of oil droplets in an aqueous phase and contains starch granules and small solid particles [25]. Starch granules are related to product stability, in particular regarding color and texture. For that matter, a maximal pasteurization temperature is recommended to avoid starch gelatinization [54]. Milling conditions were shown to modulate colloidal stability of the beverage [51]. The stability of the system is ensured by proteins, located at the interphase oil-water. The addition of emulsifiers could be required for long-term storage of the beverage. For instance, the analysis of 87 samples, either fresh artisanal-made, or UHT-treated in industry, revealed that emulsifiers like citric acid esters of mono- or diglycerides, and monoacyl glycerol, are present into industrial tiger nut beverages. On the opposite, phosphatidic acid is present only in fresh beverage, and the fresh beverage content of biotin and of L-arginine is respectively 4-fold and 10-fold higher than in UHT beverage [55].

\section{Products Obtained by Lactic Fermentation or Lactic Acid Bacteria Addition}

Until now, lactic fermentation of tiger nut beverages has been poorly investigated compared to its multiple interesting applications (e.g., from a nutritional point of view and for new product development). Fermentation of non-dairy beverages has been mainly focused on vegetable juices [56], fruits juices [17,57-60], cereal-based beverages [7,59], but also walnut and cashew nut beverages [61,62]. Although the demand for plant-based milk substitutes is increasing, the unwillingness of the mainstream consumer to try unfamiliar foods that are perceived as unappealing may be a limiting factor. Some undesired flavors could efficiently be reduced by fermentation and the flavor could be more appreciated in presence of lactic acid [8]. Lactic acid bacteria not only modify sensory characteristics of the beverages, but also can produce additional micronutrients $[63,64]$ or increase antioxidant properties [17], produce texturing compounds like exopolysaccharides [65,66], or limit undesirable microorganism development [67-69].

Besides lactic fermentation of foods and beverages, the addition of lactic acid bacteria cultures per se can bring numerous advantages by the production of compounds, like exopolysaccharides, which modify the texture [6]. The use of probiotic lactic acid bacteria to develop new functional beverages from fruits or vegetables is challenging, because the growth or survival of bacteria in such media has to be carefully examined [70-75]. But the interest is even more significant for food matrices that contain a high content of dietary fiber, and can serve as a prebiotic [71,75]. For developing countries, the selection of probiotic bacteria can be an issue to limit food insecurity [76].

The first study reporting tiger nut beverage fermentation compared the obtained product with cow milk yogurt [29]. Classical yogurt starters were used, i.e., Lactobacillus bulgaricus and Streptococcus thermophilus, to ferment tiger nut beverage. As expected, the fermentation resulted into an acidified product, at a $\mathrm{pH}$ of 3.9, which was overall less appreciated by a small untrained panel than the classical yogurt. Ukwuru et al. (2008) could not detect any difference of general acceptability between fermented tiger nut beverage and cow milk [30], but the lower acceptability of yogurt-processed tiger nut beverage compared to classical cow milk yogurt was confirmed by Sanful et al. (2009) with a broader sensory panel [31]. At this stage, the production of a fermented product from a 1:1 mix of tiger nut and cow milks seems to be the best compromise for sensory attributes, but this product loses the advantages of a plant-based yogurt. 
Tiger nut beverage fermentation performed with a Lactobacillus plantarum isolated from spontaneous fermentation demonstrated the ability of this strain to grow and to acidify the beverage [27]. Interestingly, an attempt to ferment tiger nut beverage with isolates from Ogi, a traditional fermented cereal porridge from Nigeria, resulted in a $\mathrm{pH}$ decrease up to 4.04-4.36 depending on isolated combinations [23]. In that study, four species (Lb. plantarum, Lactobacillus acidophilus, St. thermophilus and Lactobacillus brevis) were used, and three combinations of three isolates among those bacteria were used, resulting into comparable growth and acidification levels.

None of the previous studies reported a phase separation over fermentation. However, this could be expected from its composition, as the stability of this complex system depends on oil-water droplets, the protein emulsifying effect, and small solid particles. Acidification would modify protein surface properties. Moreover, in fermented non-dairy beverages, the role of exopolysaccharides, produced by bacteria, on texture and sensory quality has been demonstrated for a long time $[77,78]$. The use of exopolysaccharides producing lactic acid bacteria demonstrated their positive impact on the texture of fermented soy beverages [79] and on pureed carrots [80]. A similar approach would be of great interest for tiger nut beverages. Moreover, exopolysaccharides exert some beneficial health effects [81].

The role of proteins in beverage stability and the interest in protein fortification of food encouraged the formulation of fermented beverages from tiger nuts supplemented with soybean, sorghum, whey proteins, and caseinate $[28,82]$. Xanthan gum was also used for its thickening and stabilization effects [28]. A beverage containing sorghum, soybean, and tiger nut flours in ratio 5:3:2 and fermented with $\mathrm{Lb}$. plantarum exhibited a decrease of counts of yeasts and molds and of enterobacteria below the detection limit over $24 \mathrm{~h}$ of fermentation. This beverage contained $26.6 \%$ of proteins and $26.2 \%$ of carbohydrates on a wet base, and was positively evaluated by a sensory panel [82]. Dairy protein addition modified gel properties, leading to semi-solid, yogurt-like gels [28]. Gel stiffness and viscosity were higher and whey drainage was lower when sodium caseinate was used instead of whey proteins, hence opening a way for texture modulation by varying the protein type and content.

Compared to other lactic fermented beverages with a plant-origin, there are some features observed in the original nutritional composition of tiger nut beverages. The natural balance in good quality nutrients, likewise, unsaturated fat, minerals, and antioxidant, make tiger nut fermented beverages a potential candidate for diet complementation. The abundance of unsaturated fatty acids together with antioxidant compounds is an effective choice for lowering the dietary intake of saturated fatty acids and to limit oxidative stress. Oleic acid especially is suggested to reverse induced hyperlipidemia and to have a strong hepatoprotective effect on rats receiving a high fat/high cholesterol diet $[83,84]$. Depending on the process flow and the final protein content of tiger nut beverages, the determination of protein bioavailability is definitely required to evaluate the effect of lactic fermentation on these nutrients. Tiger nut beverage calcium content of $40 \mathrm{mg} / 100 \mathrm{~g}$ is higher than other unfortified milk alternatives having drastically lower contents of calcium, ranging from 0 to $12 \mathrm{mg} / 100 \mathrm{~g}$ [52]. The calcium bioavailability in plant-based beverages is however uncertainly comparable with the $120 \mathrm{mg} / 100 \mathrm{~g}$ cow milk calcium content, because its natural association with caseins facilitates absorption and limits sedimentation. Whether fermentation improves this parameter, it is also worth further investigation.

Tiger nut composition showed the presence of numerous phenolic compounds. However, the impact of lactic fermentation on these compounds in tiger nut beverages has never been investigated.

\section{Safety and Microbiological Quality}

In a study evaluating the parasite presence of raw tubers collected from street vendors and market places in Ghana, several parasites were found; Cryptosporidium parvum being the most common [85]. Enterobacteria and Staphylococcus sp. were also detected. Moreover, several species of mycotoxin-producing molds, Aspergillus niger, Aspergillus fumigatus, Aspergillus flavus and Penicillium italicum, were found in raw tiger nut tubers [27]. Mycotoxins were detected in both raw tiger nuts 
and beverages $[86,87]$. Aflatoxins $B_{1}$ and $G_{2}$, beauvericin and ochratoxin A were the predominant mycotoxins detected in tubers, with respectively 14, 10, 11 and 8 samples upon 83 that exhibited toxin contents over the limits of quantification.

The $\mathrm{pH}$ of tiger nut beverage is in the range 6.3-6.8 [19], which is not limiting the growth of food-borne pathogens. On tiger nut beverage samples, two microbiological profiles were observed depending on the process applied, either industrial or home-made [88]. On industrial products, which were heat-treated, no foodborne pathogen could be detected, and total viable bacteria counts were below the detection limit. On the opposite, the home-made products exhibited total viable counts in the range of 3.6-6.5 $\log \mathrm{CFU} / \mathrm{mL}$, and on certain samples, enterobacteria, Bacillus sp., Escherichia coli and yeast and molds were found. In another study [30], an increase of bacterial counts from $1.3 \log \mathrm{CFU} / \mathrm{mL}$ to $3.5 \log \mathrm{CFU} / \mathrm{mL}$ and $8.5 \log \mathrm{CFU} / \mathrm{mL}$, when stored at $4{ }^{\circ} \mathrm{C}$ or at $32{ }^{\circ} \mathrm{C}$ respectively, was observed after 6 days of storage. The samples stored at $32{ }^{\circ} \mathrm{C}$ showed spoilage signs after 6 days. The refrigerated sample remained drinkable over 14 days and the bacterial counts reached then $4.4 \log$ $\mathrm{CFU} / \mathrm{mL}$.

In tiger nut beverage, ochratoxin A was detected in 32 samples from 238, but below quantification limit. Aflatoxins B1, B2 and G2 were detected in 12, 2 and 1 samples, respectively from 238, and below the maximal limits fixed by EU.

Fermentation generally results in an increase of safety thanks to acidification and to the production of bacteriostatic compounds such as organic acids, hydrogen peroxide or bacteriocins $[9,89]$. Lactic acid bacteria also can impair the growth of mycotoxin-producing fungi, inhibit the biosynthesis of mycotoxins or degrade the compounds [89-91]. Only preliminary studies have investigated safety or the microbiological quality of the fermented tiger nut beverages. Agbaje et al. (2015) [27] isolated and identified potential foodborne pathogens, such as Staphylococcus aureus, and mycotoxinogen fungi. Traditional fermented beverages hold their own microbial ecosystem, among those lactic acid bacteria are diverse and often associated with yeasts $[7,59,92]$. To date, contrarily to other fermented vegetables [93-96], there is no data on tiger nut beverage microbiota.

\section{Conclusions and Future Research for Functional Beverages and Foods}

The interest in the lactic fermentation of plant-based beverages emerged from the search of "substitutes" to milk, due to the allergenicity or vegan-based considerations. In developing countries, the objective to fulfill nutritional requirements of people affected by food insecurity is another leading reason for this type of research. Most of these studies highlighted the value of developing featured tastes and flavors, together with an increased shelf-life of perishable products. In line with that objective, the development of fermented products from tiger nut beverages is particularly relevant.

The requirement of starters isolated from a similar origin is pointed out as a key-factor for successful fermentation [97-99]. When developing new fermented beverages from plant-origin, the choice for fermentative bacteria selected from fermented plants should be recommended. Moreover, the selection of tailored microbial starters contributes to the safety of the fermented foods and beverages by two aspects: i) the safety of the starter itself, ensured by its GRAS status and not producing toxic compounds, and ii) its ability to decrease hazards in a given food or beverage [100]. Consequently, extensive research on lactic acid bacterial starters adapted to tiger nut beverage fermentation is still required.

Funding: This work was supported by Federation BioST of the University of La Reunion and European Union project RE0017203 and the project GV/2018//040 “Implementación y optimización de procesos innovadores para la valorización de los subproductos obtenidos a partir del proceso de elaboración de la horchata" for emerging research groups from the Generalitat Valenciana. Paulo E. Munekata acknowledges the postdoctoral fellowship support from the Ministry of Economy and Competitiveness (MINECO, Spain) "Juan de la Cierva" program (FJCI-2016-29486).

Conflicts of Interest: The authors declare no conflict of interest. The funding sponsors had no role in the writing of the manuscript, and in the decision to publish. 


\section{References}

1. Slavin, J.L.; Lloyd, B. Health benefits of fruits and vegetables. Adv. Nutr. 2012, 3, 506-516. [CrossRef] [PubMed]

2. Nishida, C.; Uauy, R.; Kumanyika, S.; Shetty, P. The Joint WHO/FAO Expert Consultation on diet, nutrition and the prevention of chronic diseases: Process, product and policy implications. Public Health Nutr. 2004, 7, 245-250. [CrossRef] [PubMed]

3. Chandrasekara, A.; Josheph Kumar, T. Roots and tuber crops as functional foods: A review on phytochemical constituents and their potential health benefits. Int. J. Food Sci. 2016, 2016, 1-15. [CrossRef] [PubMed]

4. Wild, D.; Robins, G.G.; Burley, V.J.; Howdle, P.D. Evidence of high sugar intake, and low fibre and mineral intake, in the gluten-free diet. Aliment. Pharmacol. Ther. 2010, 32, 573-581. [CrossRef]

5. Vici, G.; Belli, L.; Biondi, M.; Polzonetti, V. Gluten free diet and nutrient deficiencies: A review. Clin. Nutr. 2016, 35, 1236-1241. [CrossRef]

6. Jeske, S.; Arendt, E.K. Past, present and future: The strength of plant-based dairy substitutes based on gluten-free raw materials. Food Res. Int. 2018, 110, 42-51. [CrossRef]

7. Marsh, A.J.; Hill, C.; Ross, R.P.; Cotter, P.D. Fermented beverages with health-promoting potential: Past and future perspectives. Trends Food Sci. Technol. 2014, 38, 113-124. [CrossRef]

8. Mäkinen, O.E.; Wanhalinna, V.; Zannini, E.; Arendt, E.K. Foods for special dietary needs: Non-dairy plant-based milk substitutes and fermented dairy-type products. Crit. Rev. Food Sci. Nutr. 2016, 56, 339-349. [CrossRef] [PubMed]

9. Caplice, E.; Fitzgerald, G.F. Food fermentations: Role of microorganisms in food production and preservation. Int. J. Food Microbiol. 1999, 50, 131-149. [CrossRef]

10. Hugenholtz, J. Traditional biotechnology for new foods and beverages. Curr. Opin. Biotechnol. 2013, 24, 155-159. [CrossRef]

11. Hill, C.; Guarner, F.; Reid, G.; Gibson, G.R.; Merenstein, D.J.; Pot, B.; Morelli, L.; Canani, R.B.; Flint, H.J.; Salminen, S.; et al. The International Scientific Association for Probiotics and Prebiotics consensus statement on the scope and appropriate use of the term probiotic. Nat. Rev. Gastroenterol. Hepatol. 2014, 11, 506-514. [CrossRef] [PubMed]

12. Oyewole, O.B. Lactic fermented foods in Africa and their benefits. Food Control 1997, 8, 289-297. [CrossRef]

13. Lee, C.-H. Lactic acid fermented foods and their benefits in Asia. Food Control 1997, 8, 259-269. [CrossRef]

14. Tamang, J.P.; Watanabe, K.; Holzapfel, W.H. Review: Diversity of microorganisms in global fermented foods and beverages. Front. Microbiol. 2016, 7, 377. [CrossRef] [PubMed]

15. Blandino, A.; Al-Aseeri, M.E.; Pandiella, S.S.; Cantero, D.; Webb, C. Cereal-based fermented foods and beverages. Food Res. Int. 2003, 36, 527-543. [CrossRef]

16. Di Cagno, R.; Coda, R.; De Angelis, M.; Gobbetti, M. Exploitation of vegetables and fruits through lactic acid fermentation. Food Microbiol. 2013, 33, 1-10. [CrossRef] [PubMed]

17. Fessard, A.; Kapoor, A.; Patche, J.; Assemat, S.; Hoarau, M.; Bourdon, E.; Bahorun, T.; Remize, F. Lactic fermentation as an efficient tool to enhance the antioxidant activity of tropical fruit juices and teas. Microorganisms 2017, 5, 23. [CrossRef]

18. De Castro, O.; Gargiulo, R.; Del Guacchio, E.; Caputo, P.; De Luca, P. A molecular survey concerning the origin of Cyperus esculentus (Cyperaceae, Poales): Two sides of the same coin (weed vs. crop). Ann. Bot. 2015, 115, 733-745. [CrossRef]

19. Sánchez-Zapata, E.; Fernández-López, J.; Angel Pérez-Alvarez, J. Tiger nut (Cyperus esculentus) commercialization: Health aspects, composition, properties, and food applications. Compr. Rev. Food Sci. Food Saf. 2012, 11, 366-377. [CrossRef]

20. Bamishaiye, E.; Bamishaiye, O. Tiger nut: As a plant, its derivatives and benefits. Afr. J. Food Agric. Nutr. Dev. 2011, 11, 5157-5170. [CrossRef]

21. Van Wyk, B.-E. The potential of South African plants in the development of new food and beverage products. S. Afr. J. Bot. 2011, 77, 857-868. [CrossRef]

22. Belewu, M.A.; Belewu, K. Comparative physicochemical evaluation of tigernut, soybean and coconut milk sources. Int. J. Agric. Biol. 2007, 9, 785-787.

23. Maduka, N.; Ire, F.; Njoku, H. Fermentation of tigernut by lactic acid bacteria and tigernut-milk drink fermentation by lactic acid bacteria as a potential probiotic product. Asian J. Sci. Technol. 2017, 8, 5167-5172. 
24. Oa, O. Determination of amino acids and physico-chemical properties of juice samples produced from five varieties of tigernut (Cyperus esculentus). Chem. Res. J. 2016, 1, 1-6.

25. Codina, I.; Trujillo, A.J.; Ferragut, V. Horchata. In Traditional Foods; Springer: Boston, MA, USA, 2016; pp. 345-356.

26. Sánchez-Zapata, E.; Fernández-López, J.; Pérez-Alvarez, J.A.; Soares, J.; Sousa, S.; Gomes, A.M.P.; Pintado, M.M.E. In vitro evaluation of "horchata" co-products as carbon source for probiotic bacteria growth. Food Bioprod. Process. 2013, 91, 279-286. [CrossRef]

27. Agbaje, R.B.; Oyetayo, O.V.; Ojokoh, A.O. Assessment of the microbial and physico-chemical composition of tigernut subjected to different fermentation methods. Pak. J. Nutr. 2015, 14, 742-748. [CrossRef]

28. Kizzie-Hayford, N.; Jaros, D.; Zahn, S.; Rohm, H. Effects of protein enrichment on the microbiological, physicochemical and sensory properties of fermented tiger nut milk. LWT Food Sci. Technol. 2016, 74, 319-324. [CrossRef]

29. Akoma, O.; Elekwa, U.O.; Afodunrinbi, A.T.; Onyeukwu, G.C. Yogurt from Coconut and Tigernuts. J. Food Technol. Afr. 2000, 5, 132-134. [CrossRef]

30. Ukwuru, M. Production and quality assessment of tiger nut (Cyperus esculentus) imitation milk during storage. J. Food Sci. Technol. 2008, 45, 180-182.

31. Sanful, R.E. The use of tiger-nut (Cyperus esculentus), cow milk and their composite as substrates for yoghurt production. Pak. J. Nutr. 2009, 8, 755-758. [CrossRef]

32. Sánchez-Zapata, E.; Fuentes-Zaragoza, E.; Viuda-Martos, M.; Fernández-López, J.; Sendra, E.; Sayas, E.; Pérez-Alvarez, J.A. Reclaim of the by-products from “Horchata” elaboration process. Food Bioprocess Technol. 2012, 5, 954-963. [CrossRef]

33. USDA Branded Food Products Database. Available online: https://ndb.nal.usda.gov/ndb/ (accessed on 26 November 2018).

34. Roselló-Soto, E.; Poojary, M.M.; Barba, F.J.; Lorenzo, J.M.; Mañes, J.; Moltó, J.C. Tiger nut and its by-products valorization: From extraction of oil and valuable compounds to development of new healthy products. Innov. Food Sci. Emerg. Technol. 2018, 45, 306-312. [CrossRef]

35. Kim, M.; No, S.; Yoon, S.H. Stereospecific analysis of fatty acid composition of Chufa (Cyperus esculentus L.) tuber oil. J. Am. Oil Chem. Soc. 2007, 84, 1079-1080. [CrossRef]

36. Yeboah, S.O.; Mitei, Y.C.; Ngila, J.C.; Wessjohann, L.; Schmidt, J. Compositional and structural studies of the oils from two edible seeds: Tiger nut, Cyperus esculentum, and asiato, Pachira insignis, from Ghana. Food Res. Int. 2012, 47, 259-266. [CrossRef]

37. Arafat, S.; Gaafar, A.; Basuny, A.M.; Nassef, S. Chufa tubers (Cyperus esculentus L.) as a new source of food. World Appl. Sci. J. 2009, 7, 151-156.

38. Ezeh, O.; Niranjan, K.; Gordon, M.H. Effect of enzyme pre-treatments on bioactive compounds in extracted tiger nut oil and sugars in residual meals. J. Am. Oil Chem. Soc. 2016, 93, 1541-1549. [CrossRef] [PubMed]

39. Lopéz-Cortés, I.; Salazar-García, D.C.; Malheiro, R.; Guardiola, V.; Pereira, J.A. Chemometrics as a tool to discriminate geographical origin of Cyperus esculentus L. based on chemical composition. Ind. Crops Prod. 2013, 51, 19-25. [CrossRef]

40. Codina-Torrella, I.; Guamis, B.; Trujillo, A.J. Characterization and comparison of tiger nuts (Cyperus esculentus L.) from different geographical origin: Physico-chemical characteristics and protein fractionation. Ind. Crops Prod. 2015, 65, 406-414. [CrossRef]

41. Olabiyi, A.A.; Carvalho, F.B.; Bottari, N.B.; Lopes, T.F.; da Costa, P.; Stefanelo, N.; Morsch, V.M.; Akindahunsi, A.A.; Oboh, G.; Schetinger, M.R. Dietary supplementation of tiger nut alters biochemical parameters relevant to erectile function in L-NAME treated rats. Food Res. Int. 2018, 109, 358-367. [CrossRef]

42. Adekanmi, O.K.; Oluwatooyin, O.F.; Yemisi, A.A. Influence of processing techniques on the nutrients and antinutrients of tigernut (Cyperus esculentus L.). World J. Dairy Food Sci. 2009, 4, 88-93.

43. Ekeanyanwu, R.C.; Njoku, O.; Ononogbu, I.C. The phytochemical composition and some biochemical effects of Nigerian tigernut (Cyperus esculentus L.) tuber. Pak. J. Nutr. 2010, 9, 709-715. [CrossRef]

44. El-Adawy, T.A. Nutritional composition and antinutritional factors of chickpeas (Cicer arietinum L.) undergoing different cooking methods and germination. Plant Foods Hum. Nutr. 2002, 57, 83-97. [CrossRef] [PubMed]

45. Ezeocha, V.; Ojimelukwe, P. The impact of cooking on the proximate composition and anti-nutritional factors of water yam (Dioscorea alata). J. Stored Prod. Postharvest Res. 2012, 3, 172-176. [CrossRef] 
46. Omoruyi, F.O.; Dilworth, L.; Asemota, H.N. Anti-nutritional factors, zinc, iron and calcium in some Caribbean tuber crops and the effect of boiling or roasting. Nutr. Food Sci. 2007, 37, 8-15. [CrossRef]

47. Hamdy, S.M.; Shabaan, A.M.; Abdel Latif, A.K.M.; Abdel-Aziz, A.M.; Amin, A.M. Protective effect of hesperidin and tiger nut against acrylamide toxicity in female rats. Exp. Toxicol. Pathol. 2017, 69, 580-588. [CrossRef] [PubMed]

48. Oladele, A.K.; Adebowale, J.O.; Bamidele, O.P. Phenolic profile and antioxidant activity of brown and yellow varieties of tigernut (Cyperus esculentus L.). Niger. Food J. 2017, 35, 51-59.

49. Roselló-Soto, E.; Barba, F.J.; Lorenzo, J.M.; Munekata, P.E.S.; Gómez, B.; Moltó, J.C. Phenolic profile of oils obtained from "horchata" by-products assisted by supercritical- $\mathrm{CO}_{2}$ and its relationship with antioxidant and lipid oxidation parameters: Triple TOF-LC-MS-MS characterization. Food Chem. 2019, 274, 865-871. [CrossRef] [PubMed]

50. Parker, M.L.; Ng, A.; Smith, A.C.; Waldron, K.W. Esterified phenolics of the cell walls of Chufa (Cyperus esculentus L.) tubers and their role in texture. J. Agric. Food Chem. 2000, 48, 6284-6291. [CrossRef] [PubMed]

51. Kizzie-Hayford, N.; Jaros, D.; Schneider, Y.; Rohm, H. Characteristics of tiger nut milk: Effects of milling. Int. J. Food Sci. Technol. 2015, 50, 381-388. [CrossRef]

52. Chalupa-Krebzdak, S.; Long, C.J.; Bohrer, B.M. Nutrient density and nutritional value of milk and plant-based milk alternatives. Int. Dairy J. 2018, 87, 84-92. [CrossRef]

53. FAO/WHO. FAO expert consultation. Dietary protein quality evaluation in human nutrition. In FAO Food and Nutrition Paper; FAO/WHO: Auckland, New Zealand, 2013; Vol. 92, p. 19. ISBN 9789251074176.

54. Roselló-Soto, E.; Poojary, M.M.; Barba, F.J.; Koubaa, M.; Lorenzo, J.M.; Mañes, J.; Moltó, J.C. Thermal and non-thermal preservation techniques of tiger nuts' beverage "horchata de chufa". Implications for food safety, nutritional and quality properties. Food Res. Int. 2018, 105, 945-951. [CrossRef] [PubMed]

55. Rubert, J.; Monforte, A.; Hurkova, K.; Pérez-Martínez, G.; Blesa, J.; Navarro, J.L.; Stranka, M.; Soriano, J.M.; Hajslova, J. Untargeted metabolomics of fresh and heat treatment Tiger nut (Cyperus esculentus L.) milks reveals further insight into food quality and nutrition. J. Chromatogr. A 2017, 1514, 80-87. [CrossRef] [PubMed]

56. Corona, O.; Randazzo, W.; Miceli, A.; Guarcello, R.; Francesca, N.; Erten, H.; Moschetti, G.; Settanni, L. Characterization of kefir-like beverages produced from vegetable juices. LWT Food Sci. Technol. 2016, 66, 572-581. [CrossRef]

57. Septembre-Malaterre, A.; Remize, F.; Poucheret, P. Fruits and vegetables, as a source of nutritional compounds and phytochemicals: Changes in bioactive compounds during lactic fermentation. Food Res. Int. 2017. [CrossRef] [PubMed]

58. Randazzo, W.; Corona, O.; Guarcello, R.; Francesca, N.; Germanà, M.A.; Erten, H.; Moschetti, G.; Settanni, L. Development of new non-dairy beverages from Mediterranean fruit juices fermented with water kefir microorganisms. Food Microbiol. 2016, 54, 40-51. [CrossRef]

59. Altay, F.; Karbancıglu-Güler, F.; Daskaya-Dikmen, C. A review on traditional Turkish fermented non-alcoholic beverages: Microbiota, fermentation process and quality characteristics. Int. J. Food Microbiol. 2013, 167, 44-56. [CrossRef] [PubMed]

60. Filannino, P.; Azzi, L.; Cavoski, I.; Vincentini, O.; Rizzello, C.G.; Gobbetti, M.; Di Cagno, R. Exploitation of the health-promoting and sensory properties of organic pomegranate (Punica granatum L.) juice through lactic acid fermentation. Int. J. Food Microbiol. 2013, 163, 184-192. [CrossRef]

61. Cui, X.-H.; Chen, S.-J.; Wang, Y.; Han, J.-R. Fermentation conditions of walnut milk beverage inoculated with kefir grains. LWT Food Sci. Technol. 2013, 50, 349-352. [CrossRef]

62. Tabanelli, G.; Pasini, F.; Riciputi, Y.; Vannini, L.; Gozzi, G.; Balestra, F.; Caboni, M.F.; Gardini, F.; Montanari, C. Fermented nut-based vegan food: Characterization of a home made product and scale-up to an industrial pilot-scale production. J. Food Sci. 2018, 83, 711-722. [CrossRef]

63. Yépez, A.; Russo, P.; Spano, G.; Khomenko, I.; Biasioli, F.; Capozzi, V.; Aznar, R. In situ riboflavin fortification of different kefir-like cereal-based beverages using selected Andean LAB strains. Food Microbiol. 2019, 77, 61-68. [CrossRef]

64. Capozzi, V.; Russo, P.; Dueñas, M.T.; López, P.; Spano, G. Lactic acid bacteria producing B-group vitamins: A great potential for functional cereals products. Appl. Microbiol. Biotechnol. 2012, 96, 1383-1394. [CrossRef] 
65. Caggianiello, G.; Kleerebezem, M.; Spano, G. Exopolysaccharides produced by lactic acid bacteria: From health-promoting benefits to stress tolerance mechanisms. Appl. Microbiol. Biotechnol. 2016, 100, 3877-3886. [CrossRef]

66. Galle, S.; Schwab, C.; Arendt, E.; Gänzle, M. Exopolysaccharide-forming Weissella strains as starter cultures for sorghum and wheat sourdoughs. J. Agric. Food Chem. 2010, 58, 5834-5841. [CrossRef] [PubMed]

67. Sathe, S.J.; Nawani, N.N.; Dhakephalkar, P.K.; Kapadnis, B.P. Antifungal lactic acid bacteria with potential to prolong shelf-life of fresh vegetables. J. Appl. Microbiol. 2007, 103, 2622-2628. [CrossRef] [PubMed]

68. Russo, P.; Arena, M.P.; Fiocco, D.; Capozzi, V.; Drider, D.; Spano, G. Lactobacillus plantarum with broad antifungal activity: A promising approach to increase safety and shelf-life of cereal-based products. Int. J. Food Microbiol. 2016. [CrossRef] [PubMed]

69. Trias, R.; Bañeras, L.; Montesinos, E.; Badosa, E. Lactic acid bacteria from fresh fruit and vegetables as biocontrol agents of phytopathogenic bacteria and fungi. Int. Microbiol. 2008, 11, 231-236. [CrossRef]

70. Min, M.; Bunt, C.R.; Mason, S.L.; Hussain, M.A. Non-dairy probiotic food products: An emerging group of functional foods. Crit. Rev. Food Sci. Nutr. 2018, 1-16. [CrossRef] [PubMed]

71. Salmerón, I. Fermented cereal beverages: From probiotic, prebiotic and synbiotic towards Nanoscience designed healthy drinks. Lett. Appl. Microbiol. 2017, 65, 114-124. [CrossRef] [PubMed]

72. Mridula, D.; Sharma, M. Development of non-dairy probiotic drink utilizing sprouted cereals, legume and soymilk. LWT Food Sci. Technol. 2015, 62, 482-487. [CrossRef]

73. Panghal, A.; Janghu, S.; Virkar, K.; Gat, Y.; Kumar, V.; Chhikara, N. Potential non-dairy probiotic products-A healthy approach. Food Biosci. 2018, 21, 80-89. [CrossRef]

74. Kandylis, P.; Pissaridi, K.; Bekatorou, A.; Kanellaki, M.; Koutinas, A.A. Dairy and non-dairy probiotic beverages. Curr. Opin. Food Sci. 2016, 7, 58-63. [CrossRef]

75. Corbo, M.R.; Bevilacqua, A.; Petruzzi, L.; Casanova, F.P.; Sinigaglia, M. Functional beverages: The emerging side of functional foods. Compr. Rev. Food Sci. Food Saf. 2014, 13, 1192-1206. [CrossRef]

76. Gheziel, C.; Russo, P.; Arena, M.P.; Spano, G.; Ouzari, H.-I.; Kheroua, O.; Saidi, D.; Fiocco, D.; Kaddouri, H.; Capozzi, V. Evaluating the probiotic potential of Lactobacillus plantarum strains from Algerian infant feces: Towards the design of probiotic starter cultures tailored for developing countries. Probiotics Antimicrob. Proteins 2018, 1-11. [CrossRef] [PubMed]

77. Viana de Souza, J.; Silva Dias, F. Protective, technological, and functional properties of select autochthonous lactic acid bacteria from goat dairy products. Curr. Opin. Food Sci. 2017, 13, 1-9. [CrossRef]

78. Ruas-Madiedo, P.; Hugenholtz, J.; Zoon, P. An overview of the functionality of exopolysaccharides produced by lactic acid bacteria. Int. Dairy J. 2002, 12, 163-171. [CrossRef]

79. Li, C.; Li, W.; Chen, X.; Feng, M.; Rui, X.; Jiang, M.; Dong, M. Microbiological, physicochemical and rheological properties of fermented soymilk produced with exopolysaccharide (EPS) producing lactic acid bacteria strains. LWT Food Sci. Technol. 2014, 57, 477-485. [CrossRef]

80. Juvonen, R.; Honkapää, K.; Maina, N.H.; Shi, Q.; Viljanen, K.; Maaheimo, H.; Virkki, L.; Tenkanen, M.; Lantto, R. The impact of fermentation with exopolysaccharide producing lactic acid bacteria on rheological, chemical and sensory properties of pureed carrots (Daucus carota L.). Int. J. Food Microbiol. 2015, 207, 109-118. [CrossRef] [PubMed]

81. Patel, A.; Prajapati, J. Food and health applications of exopolysaccharides produced by lactic acid bacteria. Adv. Dairy Res. 2013, 1. [CrossRef]

82. Abdulkadir, M.; Danjuma, J.B. Microbial profile and nutritional quality during the fermentation of cereal based weaning food fortified with soya bean and tiger nut using starter culture. World Sci. News 2015, 24, 103-115.

83. Chen, X.; Li, L.; Liu, X.; Luo, R.; Liao, G.; Li, L.; Liu, J.; Cheng, J.; Lu, Y.; Chen, Y. Oleic acid protects saturated fatty acid mediated lipotoxicity in hepatocytes and rat of non-alcoholic steatohepatitis. Life Sci. 2018, 203, 291-304. [CrossRef]

84. Pimentel Duavy, S.M.; Torres Salazar, G.J.; de Oliveira Leite, A.; Ecker, A.; Vargas Barbosa, N. Effect of dietary supplementation with olive and sunflower oils on lipid profile and liver histology in rats fed high cholesterol diet. Asian Pac. J. Trop. Med. 2017, 10, 539-543. [CrossRef] [PubMed]

85. Ayeh-Kumi, P.F.; Tetteh-Quarcoo, P.B.; Duedu, K.O.; Obeng, A.S.; Addo-Osafo, K.; Mortu, S.; Asmah, R.H. A survey of pathogens associated with Cyperus esculentus L (tiger nuts) tubers sold in a Ghanaian city. BMC Res. Notes 2014, 7, 343. [CrossRef] [PubMed] 
86. Rubert, J.; Soler, C.; Mañes, J. Occurrence of fourteen mycotoxins in tiger-nuts. Food Control 2012, 25, 374-379. [CrossRef]

87. Rubert, J.; Sebastià, N.; Soriano, J.M.; Soler, C.; Mañes, J. One-year monitoring of aflatoxins and ochratoxin A in tiger-nuts and their beverages. Food Chem. 2011, 127, 822-826. [CrossRef] [PubMed]

88. Sebastià, N.; El-Shenawy, M.; Mañes, J.; Soriano, J.M. Assessment of microbial quality of commercial and home-made tiger-nut beverages. Lett. Appl. Microbiol. 2012, 54, 299-305. [CrossRef] [PubMed]

89. Juodeikiene, G.; Bartkiene, E.; Viskelis, P.; Urbonaviciene, D.; Eidukonyte, D.; Bobinas, C. Fermentation Processes Using Lactic Acid Bacteria Producing Bacteriocins for Preservation and Improving Functional Properties of Food Products; Petre, M., Ed.; InTech: Rijeka, Croatia, 2012; ISBN 978-953-307-820-5.

90. Dalié, D.K.D.; Deschamps, A.M.; Richard-Forget, F. Lactic acid bacteria-Potential for control of mould growth and mycotoxins: A review. Food Control 2010, 21, 370-380. [CrossRef]

91. Chiocchetti, G.M.; Jadán-Piedra, C.; Monedero, V.; Zúñiga, M.; Vélez, D.; Devesa, V. Use of lactic acid bacteria and yeasts to reduce exposure to chemical food contaminants and toxicity. Crit. Rev. Food Sci. Nutr. 2018, 1-12. [CrossRef]

92. Sõukand, R.; Pieroni, A.; Biró, M.; Dénes, A.; Dogan, Y.; Hajdari, A.; Kalle, R.; Reade, B.; Mustafa, B.; Nedelcheva, A.; et al. An ethnobotanical perspective on traditional fermented plant foods and beverages in Eastern Europe. J. Ethnopharmacol. 2015, 170, 284-296. [CrossRef]

93. Wouters, D.; Grosu-Tudor, S.; Zamfir, M.; De Vuyst, L. Bacterial community dynamics, lactic acid bacteria species diversity and metabolite kinetics of traditional Romanian vegetable fermentations. J. Sci. Food Agric. 2013, 93, 749-760. [CrossRef]

94. Padonou, W.S.; Nielsen, D.S.; Hounhouigan, J.D.; Thorsen, L.; Nago, M.C.; Jakobsen, M. The microbiota of Lafun, an African traditional cassava food product. Int. J. Food Microbiol. 2009, 133, 22-30. [CrossRef]

95. Peng, Q.; Jiang, S.; Chen, J.; Ma, C.; Huo, D.; Shao, Y.; Zhang, J. Unique Microbial Diversity and Metabolic Pathway Features of Fermented Vegetables from Hainan, China. Front. Microbiol. 2018, 9, 399. [CrossRef] [PubMed]

96. Wuyts, S.; Van Beeck, W.; Oerlemans, E.F.M.; Wittouck, S.; Claes, I.J.J.; De Boeck, I.; Weckx, S.; Lievens, B.; De Vuyst, L.; Lebeer, S. Carrot juice fermentations as man-made microbial ecosystems dominated by lactic acid bacteria. Appl. Environ. Microbiol. 2018, 84. [CrossRef] [PubMed]

97. Beganović, J.; Kos, B.; Leboš Pavunc, A.; Uroić, K.; Jokić, M.; Šušković, J. Traditionally produced sauerkraut as source of autochthonous functional starter cultures. Microbiol. Res. 2013. [CrossRef] [PubMed]

98. Di Cagno, R.; Surico, R.F.; Paradiso, A.; De Angelis, M.; Salmon, J.-C.; Buchin, S.; De Gara, L.; Gobbetti, M. Effect of autochthonous lactic acid bacteria starters on health-promoting and sensory properties of tomato juices. Int. J. Food Microbiol. 2009, 128, 473-483. [CrossRef] [PubMed]

99. Fessard, A.; Bourdon, E.; Payet, B.; Remize, F. Identification, stress tolerance, and antioxidant activity of lactic acid bacteria isolated from tropically grown fruits and leaves. Can. J. Microbiol. 2016, 62, 550-561. [CrossRef]

100. Capozzi, V.; Fragasso, M.; Romaniello, R.; Berbegal, C.; Russo, P.; Spano, G.; Capozzi, V.; Fragasso, M.; Romaniello, R.; Berbegal, C.; et al. Spontaneous food fermentations and potential risks for human health. Fermentation 2017, 3, 49. [CrossRef]

(C) 2018 by the authors. Licensee MDPI, Basel, Switzerland. This article is an open access article distributed under the terms and conditions of the Creative Commons Attribution (CC BY) license (http://creativecommons.org/licenses/by/4.0/). 